\title{
Lignin and Activity Enzymatic in Susceptibility to Weathering Damage on Soybean Seeds
}

\author{
Elisa de Melo Castro ${ }^{1}$, João Almir Oliveira ${ }^{1}$, Heloísa Oliveira dos Santos ${ }^{1}$, Édila Vilela de Resende Von Pinho ${ }^{1}$, \\ Amador Eduardo de Lima ${ }^{1}$, Rucyan Walace Pereira ${ }^{1}$, Marcus Vinicius Prado Alves ${ }^{1} \&$ Fabiano França da Silva ${ }^{2}$ \\ ${ }^{1}$ Departamento de Agricultura, Universidade Federal de Lavras, Lavras, Brazil \\ ${ }^{2}$ Departamento de Produção Vegetal, Universidade de São Paulo, Escola Superior de Agricultura "Luiz de \\ Queiroz", Piracicaba, Brazil \\ Correspondence: Elisa de Melo Castro, Departamento de Agricultura, Universidade Federal de Lavras, CEP: \\ 37200-000 Lavras, MG, Brazil. Tel: 55-353-829-1014. E-mail: elisa.castro@ufla.br
}

Received: April 6, $2019 \quad$ Accepted: May 26, $2019 \quad$ Online Published: July 31, 2019

doi:10.5539/jas.v11n11p203 URL: https://doi.org/10.5539/jas.v11n11p203

\begin{abstract}
The aim of this study was to evaluate the isoenzyme activity in soybean seeds with different lignin contents subjected to harvest delay with artificial incidence of rainfall before and after storage. The experiment was conducted in a randomized block design with three replicates and a $5 \times 3 \times 2$ factorial design, being five soybean cultivars, three harvest seasons ( $\mathrm{R} 8, \mathrm{R} 8$ + one pre-harvest rainfall simulation, and $\mathrm{R} 8$ + two pre-harvest rainfall simulations), and two storage seasons ( 0 and 180 days). The pre-harvest rainfall simulations were performed through irrigation at the intensity of $30 \mathrm{~mm}$ of water until the pods were soaked and then collected after reached $18 \%$ water content. Seeds were evaluated regarding chemical composition (lignin content), physiological quality (germination, accelerated aging), and enzymatic activity (catalase, esterase, alcohol dehydrogenase, malate dehydrogenase, and isocitratelyase). The cultivar AS 7307 RR showed higher lignin content in the integument and higher physiological quality. The harvest delay and the artificial incidence of rainfallpromotesvariation in the electrophoretic pattern of the enzymes catalase, esterase, alcohol dehydrogenase; malate dehydrogenase, and isocitratelyase for stored and non-stored seeds.
\end{abstract}

Keywords: Glycine max, physiological quality, storage, enzymes

\section{Introduction}

Soy is one of the most economically important crops for Brazil. Therefore, companies producing soybean seeds have sought genotypes that are more tolerant to the exposure of climatic storms in order to obtain high quality seeds.

In the soybean production process, it is recommended to harvest at the closest possible moment of physiological maturity. According to Ferreira et al. (2015), at the stage near physiological maturity, seeds have a high level of vigor and high water content and these facts involve the improvement of post-harvest techniques.

The intensity of damages caused by environmental effects in any seed development stages is variable according to genetic factors inherent of each cultivar (Huth et al., 2016).

One of the main causes that undermine the quality of soybean seeds is moisture damage during the physiological post-maturity period, in which seeds are exposed in the field, since seeds are hygroscopic and have their moisture content conditioned to the relative humidity of the environment, besides being sensitive to exposure to alternating cycles of high and low humidity during the pre-harvest period (Huth et al., 2016).

Because of seed damages, there is intensification of the metabolic processes, which can cause oxidative stress, leading to the formation of reactive oxygen species (ROS) and free radicals (Santos et al., 2015). There are enzymes involved in seed deterioration processes which have a great potential as molecular markers to monitor and characterize the physiological quality of seeds (Santos et al., 2016), besides providing a better understanding of the causes for reduced vigor and viability (Galvão et al., 2014).

Caixeta et al. (2014) report that the increase in seed deterioration caused by harvest delay was spelling by the increase in the enzymatic activity of alcohol dehydrogenase. In soybean seeds, particularities such as water 
semipermeability and high lignin content may contribute for obtaining good quality seeds (Cavariani et al., 2009). It can also influence seed quality, including germination, shattering, hardseed, water permeability, and resistance to seed deterioration (Bellaloui et al., 2017). Although there are studies that show the influence of lignin content on seeds subjected to climatic storms, there is lack of information on this subject, mainly related to isoenzyme studies. Thus, this research aimed to study the isoenzymatic activity in soybean seeds with different lignin contents subjected to harvest delay with artificial incidence of rainfall, before and after storage.

\section{Materials and Methods}

The experiment was implemented in a field of seed production in an area irrigated by center pivot in the city of Iraí de Minas, in the state of Minas Gerais, Brazil. The city is located in the TriânguloMineiro region under the geographical coordinates $18^{\circ} 59^{\prime} 23^{\prime \prime} \mathrm{S}$ and $47^{\circ} 28^{\prime} 33^{\prime \prime} \mathrm{W}$ and 1,029 m altitude.

The experiment was conducted with five cultivars: NK7059 RR, SYN1163 RR, SYN9070 RR, AS7307 RR, and SYN 1283 RR and three harvest seasons. Seeds were harvested at the R8, R8 stage plus a pre-harvest rainfall simulation and R8 plus two pre-harvest rainfall simulations. The pre-harvest rainfall simulations were performed through center pivot irrigation at the intensity of approximately $30 \mathrm{~mm}$ of water until the pods were soaked and the harvesting later after seeds reached $18 \%$ water content. Plots were composed of 6 lines of $12 \mathrm{~m}$ spaced $0.5 \mathrm{~m}$ between lines and 20 seeds $\mathrm{m}^{-1}$, with two lines of the central region used as a useful area space plot. Harvesting was performed manually by uprooting plants and drying in the sun. Seeds were threshed with the aid of a thresher with a drum beater and then packed in a paper bag and sent to the city of Lavras, MG, where they were stored for 180 days under ambient conditions in the Seed Processing Unit at the Federal University of Lavras (UFLA). Only seeds retained in a 13/64 circular screen sieve were used for evaluations.

The laboratory study was conducted at the Laboratory Center of Seed Analysis, Agriculture Department, Federal University of Lavras. Lavras city is in southern Minas Gerais state that, according to Köppen classification presents climate Cwa (Ometo, 1981). It is situated at an altitude $918 \mathrm{~m}$, at $21^{\circ} 14$ south latitude and $45^{\circ} 00$ west longitude.

For the determination of the lignin content, only freshly harvested seeds were used, being six replicates of 50 seeds for each cultivar which were first immersed in water for 12 hours. Following, the seeds coats were removed and dried at $105{ }^{\circ} \mathrm{C}$ for 16 hours. The obtained dried matter was crushed, homogenized and subjected to successive centrifugation (3300 rpm for four minutes) with different buffer solutions (sodium and potassium phosphate/Triton $\mathrm{X}-100 / 1.0 \mathrm{M} \mathrm{NaCl} /$ acetone), to obtain protein-free cell wall fraction. Was performed by quantification of lignin LTGA method (linotioglicólico acid) (Capeleti et al., 2005).

In the germination tests, 300 seeds per cultivarwere used. The seeds were sown on paper type Germitest moistened with distilled water at a ratio of 2.5 times the weight of the paper, aiming adequately moistened and uniformity of test conditions. The seeds remain in the germination chamber which was set to $25^{\circ} \mathrm{C}$. Evaluations were done at eight days (final count) after sowing, computing the normal seedlings percentage, according to the criteria set by the Rules for Seed Analysis (MAPA, 2009).

For the accelerated aging were used gerbox-type transparent acrylic boxes $(11.0 \times 11.0 \times 3.5 \mathrm{~cm})$ adapted with a hanging aluminum screen, containing $40 \mathrm{~mL}$ of distilled water and a single layer of seeds on the hanging screen. Subsequently, these boxes were kept in a B.O.D. (Biochemical Oxygen Demand) at $42{ }^{\circ} \mathrm{C}$ for $72 \mathrm{~h}$ (Dutra \& Vieira, 2004). After this period, the seeds were submitted to the germination test (MAPA, 2009).

For the enzymatic evaluations, two samples of 50 seeds of each treatment were collected. These seeds were macerated with PVP and liquid nitrogen in ice. Later they were stored at $-86^{\circ} \mathrm{C}$, until the extraction moment. For the enzymes extraction, the extraction buffer (TrisHCl $0.2 \mathrm{M} \mathrm{pH} 8+0.1 \%$ of $\beta$-mercaptoethanol) was added in the proportion of $250 \mu \mathrm{L}$ for $100 \mathrm{mg}$ of seeds powder. The material was homogenized in vortex and kept in refrigerator during $12 \mathrm{~h}$ followed by the centrifugation at $14000 \mathrm{rpm}$ for $30 \mathrm{~min}$ at $4{ }^{\circ} \mathrm{C}$. Then, $60 \mu \mathrm{L}$ of supernatant in polyacrilamide gel was applied. The electrophoretic run was realized in a discontinuous polyacrylamide gel system at 7.5 (separating gel) and 4.5\% (concentrating gel) using Tris-glycine pH 8.9 as standard buffer in the gel electrode system. The gel was ran at $150 \mathrm{~V}$ for $5 \mathrm{~h}$. At the end of running, the gels were revealed for alcohol dehydrogenase (EC 1.1.1.1, ADH), malate dehydrogenase (EC 1.1.1.37, $\mathrm{MDH}$ ), catalase (EC.1.11.1.6, CAT), esterase (EC 3.1.1.1, EST), and isocitratelyase (EC 4.1.3.1, ICL) according to the protocols established by Alfenas

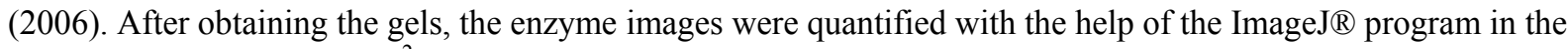
squared millimeter unit $\left(\mathrm{mm}^{2}\right)$. 
For the statistical analysis of germination and accelerated aging tests, treatments were arranged in a $5 \times 3 \times 2$ factorial design involving five cultivars, three harvesting periods and two storage periods. Data were submitted to analysis of variance. The obtained average was grouped by Scott-Knott test at $5 \%$ probability.

The lignin content was determined for the five studied cultivars and six replicates were analyzed. The statistical analysis was performed in a completely randomized design (CRD) and the averages were grouped by the Scott-Knott test at $5 \%$ probability.

For the expression of isoenzymes, the electrophoretic profiles based on the presence, absence and intensity of bands were evaluated.

\section{Results and Discussion}

It was possible to distinguish seeds from soybean cultivars according to the lignin content in the tegument. Cultivars SYN 903 RR $(0.3017 \mathrm{~g} \%)$ and SYN $9070 \mathrm{RR}(0.2967 \mathrm{~g} \%)$ showed intermediate levels and did not differ among themselves whereas the cultivar AS $7307 \mathrm{RR}$ showed the highest content ( $0.4433 \mathrm{~g} \%)$. Cultivars SYN 1163 RR $(0.2233 \mathrm{~g} \%)$ and NK $7059 \mathrm{RR}(0.1933 \mathrm{~g} \%)$ showed the lowest lignin contents.

Based on the analysis of variance results, regarding germination and accelerated aging, there was a significant difference $(\mathrm{p}<0.05)$ for the isolated factors cultivar, harvest season, storage season, and cultivar $\times$ harvest season interaction.

After each harvest season evaluation, it was verified that cultivars AS 7307RR and SYN 1283RR, with higher lignin contents, showed better performance in $\mathrm{R} 8$ and the same was verified for $\mathrm{R} 8+1$, both for the germination test and for the accelerated aging. Regarding the harvest delay with artificial incidence of rainfall, this did not cause a decline in the germination percentage of seeds when evaluated by germination test and accelerated aging because possibly the water stress caused was not enough to cause such severe damages (Table 1).

Table 1. Average values as percentage of germination and accelerated aging of seeds from different soybean cultivars with harvest delay

\begin{tabular}{|c|c|c|c|c|c|c|}
\hline \multirow{2}{*}{ Cultivars } & \multicolumn{3}{|c|}{ Germination (\%) } & \multicolumn{3}{|c|}{ Accelerated aging (\%) } \\
\hline & R8 & $\mathrm{R} 8+1$ & $\mathrm{R} 8+2$ & $\mathrm{R} 8$ & $\mathrm{R} 8+1$ & $\mathrm{R} 8+2$ \\
\hline NK 7059 RR & $82 \mathrm{~B} \mathrm{c}$ & $85 \mathrm{~B} \mathrm{a}$ & $91 \mathrm{Aa}$ & $48 \mathrm{~B} \mathrm{~b}$ & $50 \mathrm{~B} \mathrm{~b}$ & $66 \mathrm{Ab}$ \\
\hline SYN 1163 RR & $68 \mathrm{~B} \mathrm{~d}$ & $63 \mathrm{~B} \mathrm{c}$ & $90 \mathrm{~A} \mathrm{a}$ & $30 \mathrm{~B} \mathrm{c}$ & $33 \mathrm{~B} \mathrm{c}$ & $72 \mathrm{Ab}$ \\
\hline SYN $9070 \mathrm{RR}$ & $77 \mathrm{~B} \mathrm{c}$ & $74 \mathrm{~B} \mathrm{~b}$ & $95 \mathrm{~A} \mathrm{a}$ & $53 \mathrm{~B} \mathrm{~b}$ & $51 \mathrm{~B} \mathrm{~b}$ & $88 \mathrm{~A} \mathrm{a}$ \\
\hline AS 7307 RR & $98 \mathrm{~A} \mathrm{a}$ & $91 \mathrm{~A} \mathrm{a}$ & $95 \mathrm{~A} \mathrm{a}$ & $94 \mathrm{~A} \mathrm{a}$ & $82 \mathrm{~A} \mathrm{a}$ & $86 \mathrm{~A} \mathrm{a}$ \\
\hline SYN 1283 RR & $89 \mathrm{~A} \mathrm{~b}$ & $87 \mathrm{~A} \mathrm{a}$ & $85 \mathrm{~A} \mathrm{~b}$ & $86 \mathrm{~A} \mathrm{a}$ & $75 \mathrm{~A} \mathrm{a}$ & $76 \mathrm{Ab}$ \\
\hline
\end{tabular}

Note. Averages followed by the same lowercase letters on the columns and capital on the rows do not differ from each other by Scott-Knott test at 5\%. R8: harvest stage; R8+1: harvest stage R8 plus the rainfall simulation in the pre-harvest; and R8+2: harvest stage R8 plus the simulation of two rainfalls in the pre-harvest.

In a study performed by Huth et al. (2016), it was verified that soybean cultivars with lignin contents in the tegument of $4.2 \%$ and $2.6 \%$ were less susceptible to damages caused by water stress, which occurred through simulated rainfall. However, Carvalho et al. (2014) observed that not necessarily seeds of soybean cultivars with higher lignin contents show higher physiological quality.

Zuffo et al. (2017a) report that the germination potential tends to decrease as the seeds remain in the field after physiological maturity, a fact that did not occur in this study. However, these authors allowed a greater exposure time to the climatic storms, since seeds remained in the field until the 10 days after the reproductive R8.

These results indicate that each genotype behaves differently in relation to the water oscillations and that seeds from cultivars with higher lignin content have lower permeability. According to Felisberto et al. (2015), factors such as genetic background, growth habit, maturation group, and other attributes favor variations among cultivars.

The storage season was significant only for the accelerated aging test. Seeds showed an average of $71 \%$ of germination after accelerated aging and a decrease to $62 \%$ when submitted to storage. This decrease in vigor is due to storage time because the deterioration process of stored seeds is inevitable and accelerated aging enhances the observation of this loss of vigor. According to Hu et al. (2012), even under optimal storage conditions, seeds undergo a variety of biochemical and metabolic changes, including lipid peroxidation, enzymatic inactivation, and rupture of cell membranes. 
Regarding the expression of the enzyme ADH, it was observed greater expression for cultivar NK 7059 RR in non-stored seeds (Figure 1) when harvested in R8+1. The cultivar SYN 9070 RR showed higher band intensity for seeds harvested in R8 and R8+1 and SYN 1283 RR showed higher expression in harvest seasons with rainfall incidence. The cultivar AS 7307 RR that showed better performance in germination and aging tests showed low expression for the three harvest seasons.

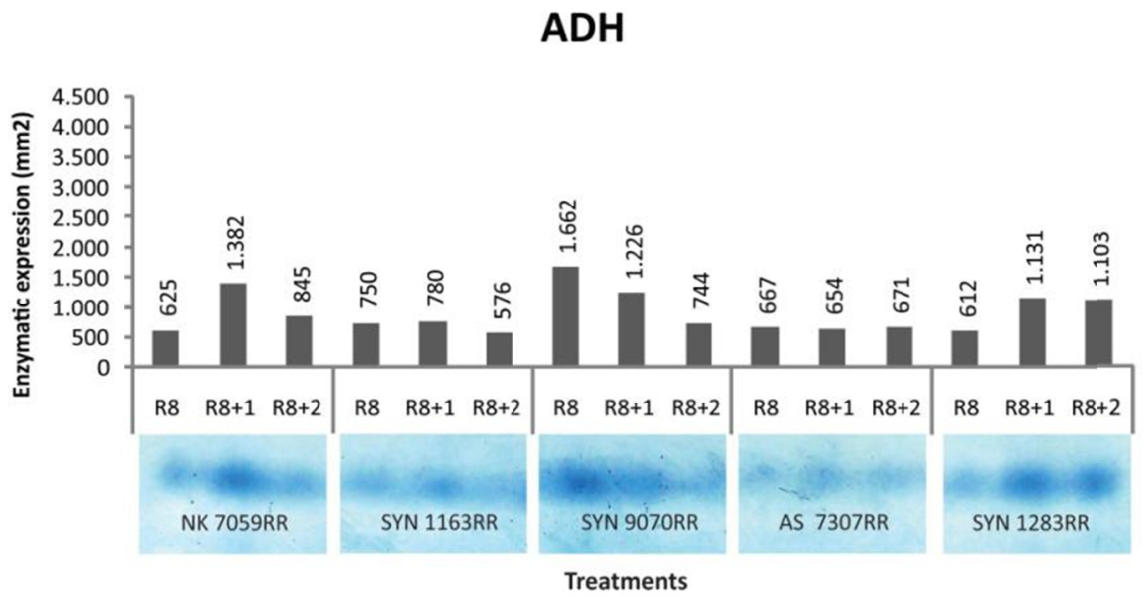

Figure 1. Alcohol Dehydrogenase enzyme expression at zero days of storage of different soybean seeds cultivars submitted to harvest delay and artificial rainfall in pre-harvest (R8; R8+1 rainfall in pre-harvest;

$\mathrm{R} 8+2$ rainfalls in pre-harvest)

At 180 days of storage (Figure 2), the ADH expression was not very evident for cultivar SYN 1163 RR, which showed a tendency of reduction in the expression of this enzyme when compared to seeds not submitted for storage, which may be related to the accumulation of acetaldehyde. The ADH converts acetaldehyde into ethanol, a compound with lower toxicity and slows down the deterioration process (Veiga et al., 2010). The seed becomes more susceptible to the deleterious action of acetaldehyde when the expression of this enzyme is reduced (Castro et al., 2017).

\section{ADH}

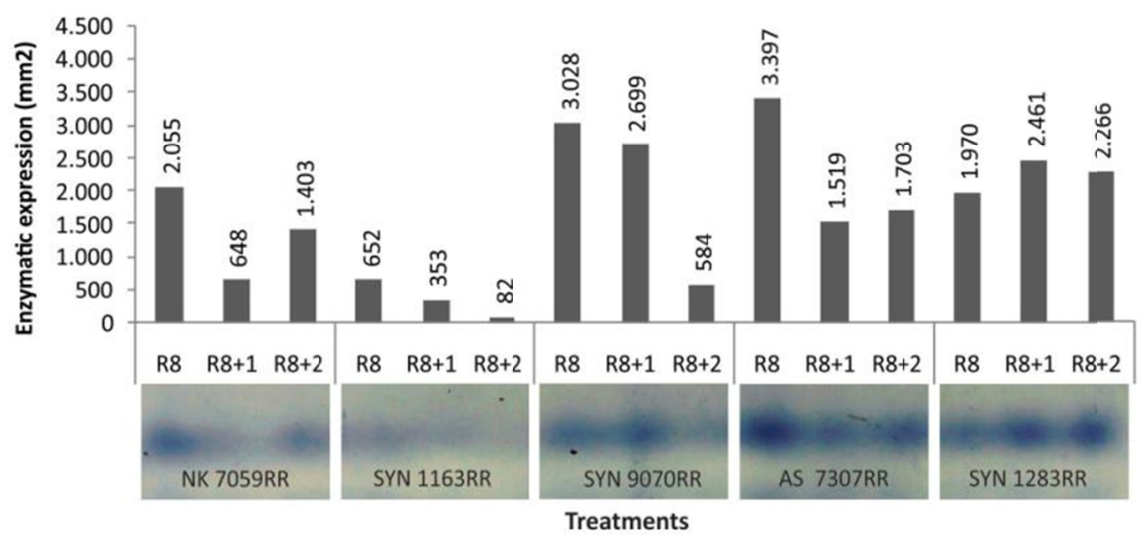

Figure 2. Alcohol Dehydrogenase enzyme expression at 180 days of storage of different soybean seeds cultivars submitted to harvest delay and artificial rainfall in pre-harvest $(\mathrm{R} 8$; $\mathrm{R} 8+1$ rainfall in pre-harvest;

$\mathrm{R} 8+2$ rainfalls in pre-harvest)

Also with respect to ADH, the highest expression of this enzyme was observed for cultivars AS 7307 RR and SYN 1283 RR at 180 days of storage (Figure 2). Carvalho et al. (2014) and Baldoni et al. (2019) also found higher ADH expression in soybean cultivars that showed better physiological quality. 
For the malate dehydrogenase (MDH) enzymatic system, no variation in the expression was observed among cultivars and harvest seasons for the non-stored seeds (Figure 3). This result can be justified because this enzyme is found in association with a large amount of organelles, which can confer a stability in its expression. The MDH catalyzes the conversion of malate to oxaloacetate in the Krebs cycle, producing NADH, which is essential in the ATP production and intermediate compounds essential for the cell functioning. During seed germination, this enzyme also acts in the gluconeogenesis process responsible for the generation of sucrose from triacylglycerols present inside the oleosomes in the seed storage tissues (Taiz \& Zeiger, 2013). In Figure 3 is shown that the cultivar SYN 1163 RR showed higher expression in the second harvest season $(\mathrm{R} 8+1)$. This higher expression may be related to its quality, as this cultivar showed lower physiological quality for seeds harvested in $\mathrm{R} 8+1$ when evaluated by the germination test and accelerated aging (Table 1).

\section{MDH}

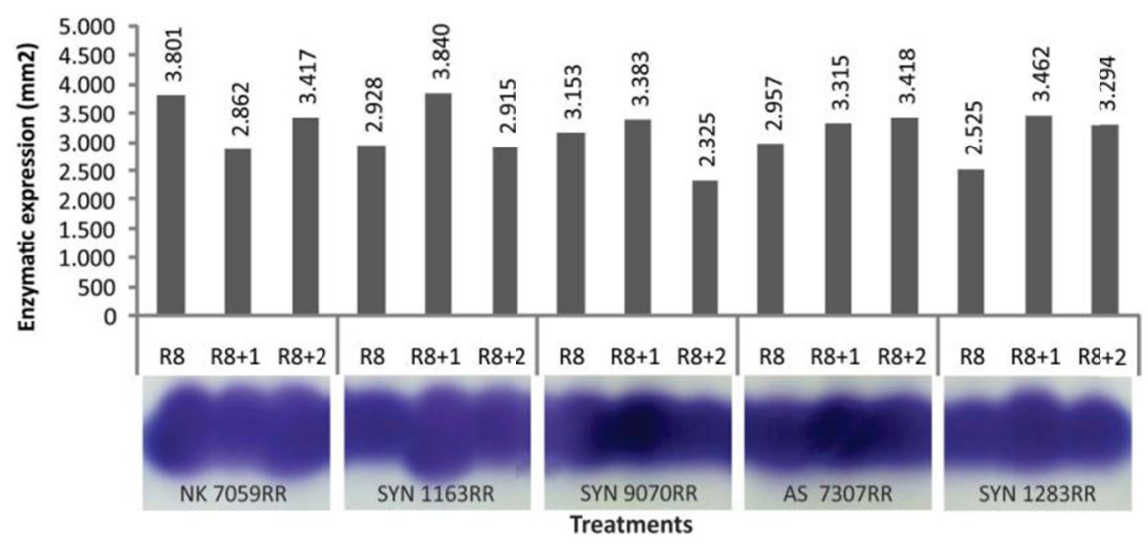

Figure 3. Malato Dehydrogenase enzyme expression at zero days of storage of different soybean seeds cultivars submitted to harvest delay and artificial rainfall in pre-harvest (R8; R8+1 rainfall in pre-harvest;

$\mathrm{R} 8+2$ rainfalls in pre-harvest)

At 180 days of storage (Figure 4), the cultivar SYN $1283 \mathrm{RR}$ had an expressive increase when harvested in R $8+2$. Possibly, the highest MDH expression is because this cultivar belongs to a late maturation group (8.3) and has remained for a longer time in the field of seed production, being more influenced by the incidence of artificial rainfall in the pre-harvest and climatic storms. This cultivar also showed a lower percentage of germination and accelerated aging when harvested in R8+2 (Table 1). Higher MDH expression indicates increased respiratory activity and possibly the advancement of the deterioration process (Catão et al., 2016).

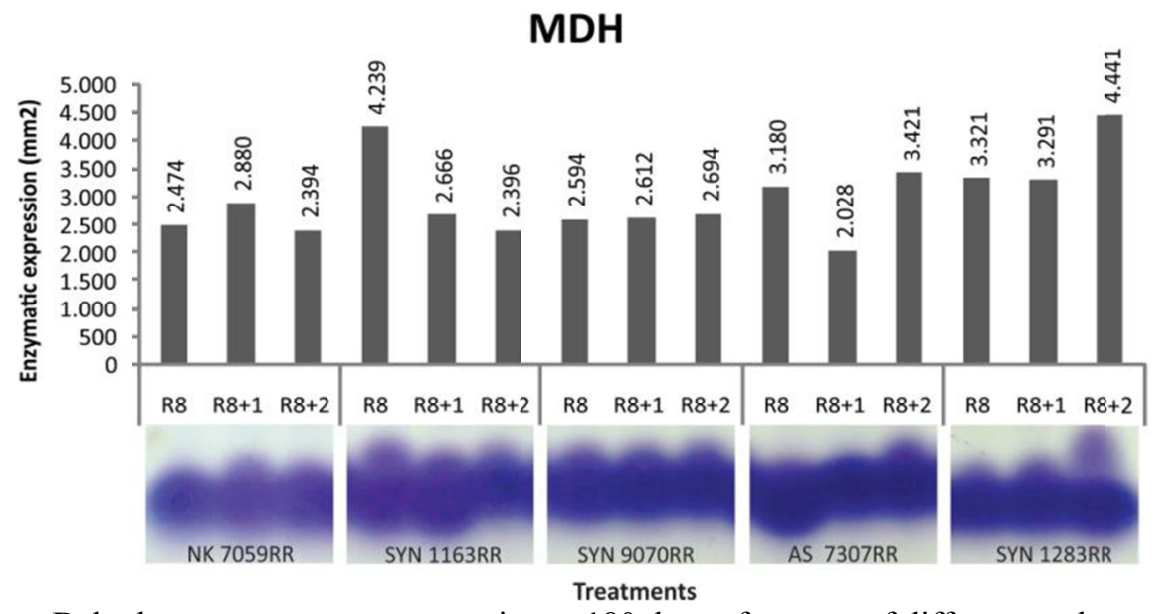

Figure 4. Malato Dehydrogenase enzyme expression at 180 days of storage of different soybean seeds cultivars submitted to harvest delay and artificial rainfall in pre-harvest (R8; R8+1 rainfall in pre-harvest;

$\mathrm{R} 8+2$ rainfalls in pre-harvest) 
With respect to the electrophoretic profiles for the enzyme catalase (CAT) (Figure 5), it was observed low expression for cultivars SYN 1283 RR and AS 7307 RR, when compared with the other cultivars.

\section{CATALASE}

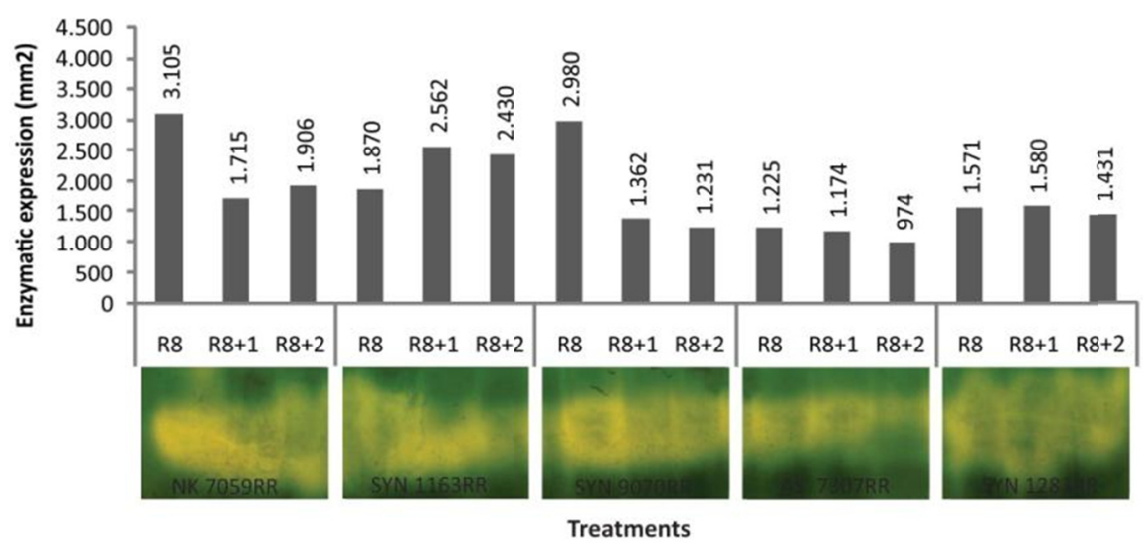

Figure 5. Catalase enzyme expression at zero days of storage of different soybean seeds cultivars submitted to harvest delay and artificial rainfall in pre-harvest (R8; $\mathrm{R} 8+1$ rainfall in pre-harvest; $\mathrm{R} 8+2$ rainfalls in pre-harvest)

According to Figure 6 (180 days of storage), the delay effect was greater with storage, where there was a reduction in enzyme expression for all cultivars from the first to the third harvest season, in which seeds remained longer in the field, thus subjected to stress conditions. It is emphasized that the reduction of the catalase expression can increase the formation of hydrogen peroxide in cells, making seeds more sensitive to the effects of free radicals and hence more subjected to viability loss. This result corroborates that found by Baldoni et al. (2013), which worked with soybean seeds harvested at the R8 stage and 15 days after this stage and verified that the expression of this enzyme was higher in seeds harvested at the R8 stage. Timoteo and Marcos Filho (2013) observed a decrease or even absence of activity of this enzyme in the most deteriorated seeds and reported that the lower CAT expression can make seeds more sensitive to the effects of free radicals and increase the formation of cellular peroxide, becoming them most sensitive to viability loss.

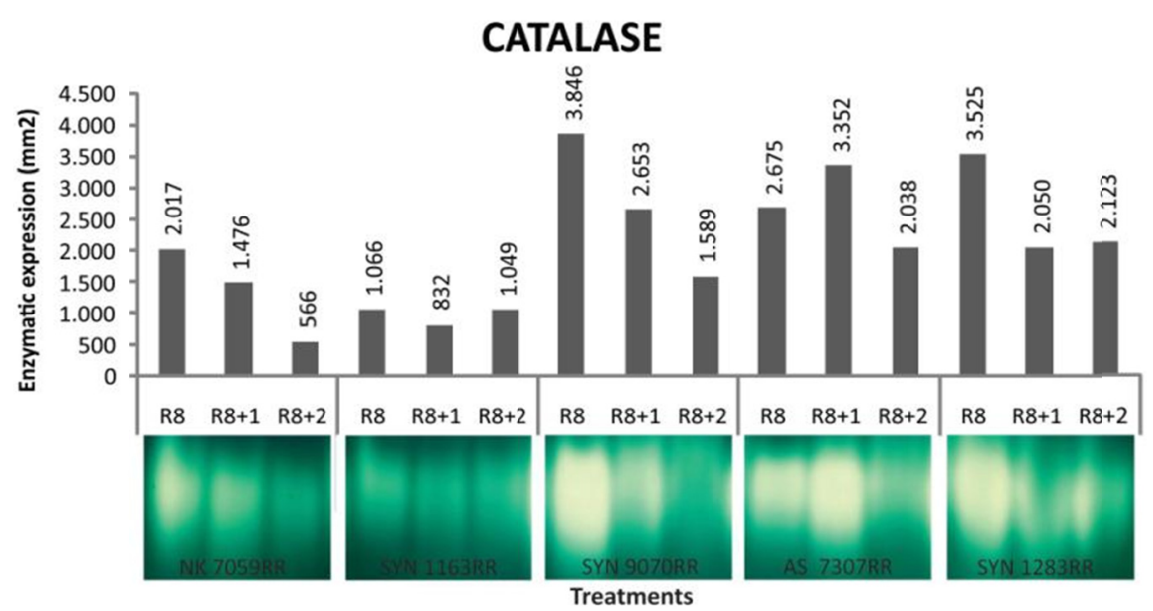

Figure 6. Catalase enzyme expression at 180 days of storage of different soybean seeds cultivars submitted to harvest delay and artificial rainfall in pre-harvest (R8; R8+1 rainfall in pre-harvest; $\mathrm{R} 8+2$ rainfalls in pre-harvest)

Recent studies have shown that loss of seed viability during storage is accompanied by increased reactive oxygen species (Eros) (Jeevan Kumar et al., 2015). Several defense mechanisms are activated to combat these free radicals, including the free radical scavenging enzymes, such as catalase, peroxidase, and superoxide dismutase. However, in this study, it is worth noting that the excess of these radicals reduced expressions of some enzymes. 
Differences in esterase (EST) enzyme expression were observed in seeds submitted to different treatments. It is observed more expression of this enzyme in the second harvest season for the non-stored seeds (Figure 7), for researched cultivars. Among them, AS 7307 RR showed the highest expression. This cultivar also showed higher lignin content and higher physiological quality. Based on the above, the greater esterase expression may be related to the function of this enzyme to unfold lipids and provide energy for the synthesis of new molecules in seedlings.

\section{ESTERASE}

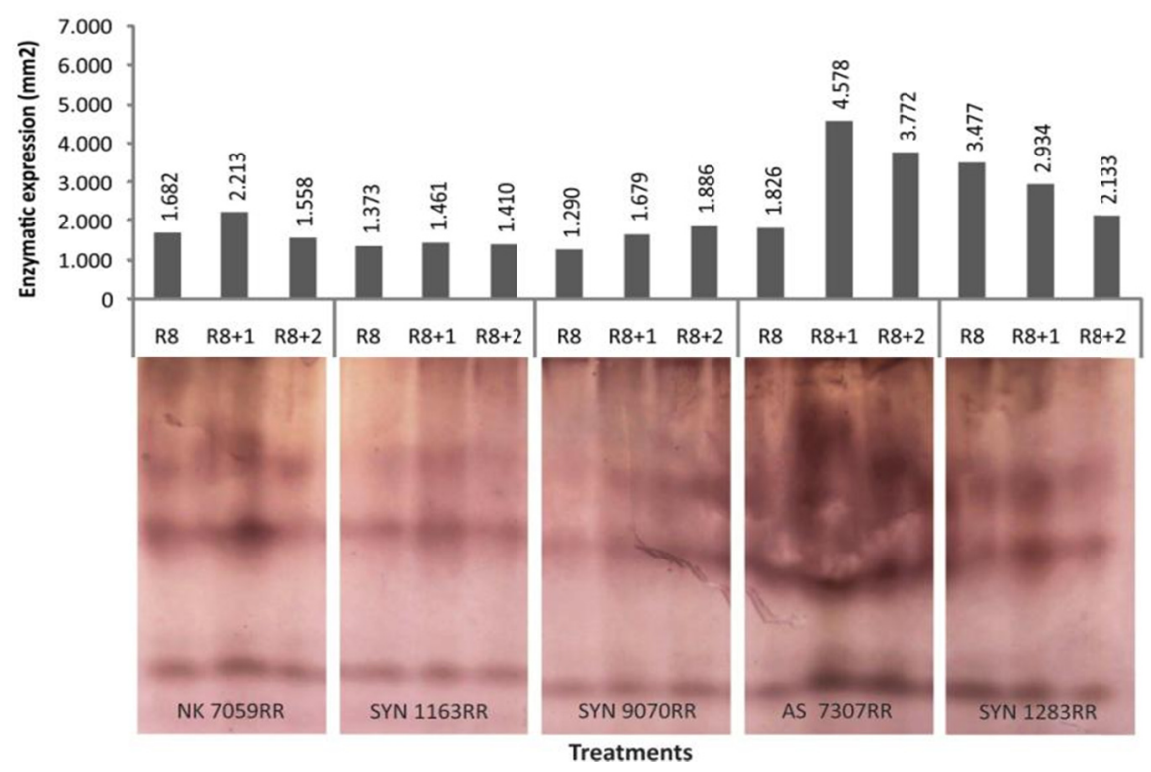

Figure 7. Esterase enzyme expression at zero days of storage of different soybean seeds cultivars submitted to harvest delay and artificial rainfall in pre-harvest $(\mathrm{R} 8 ; \mathrm{R} 8+1$ rainfall in pre-harvest; $\mathrm{R} 8+2$ rainfalls in pre-harvest)

After the storage period (180 days), the cultivar AS 7307 RR showed lower expression, which shows that this enzyme is acting in the degradation (Figure 8). The process of lipid degradation during seed germination is relevant for the resumption of embryo and embryonic axis growth, especially in lipid-rich seeds, such as soybean (Veiga et al., 2010). Similar result was verified by Vieira et al. (2013) studying the deterioration of soybean seeds submitted to harvest delay and storage, which observed lower expression of the esterase enzyme after six months of storage. 


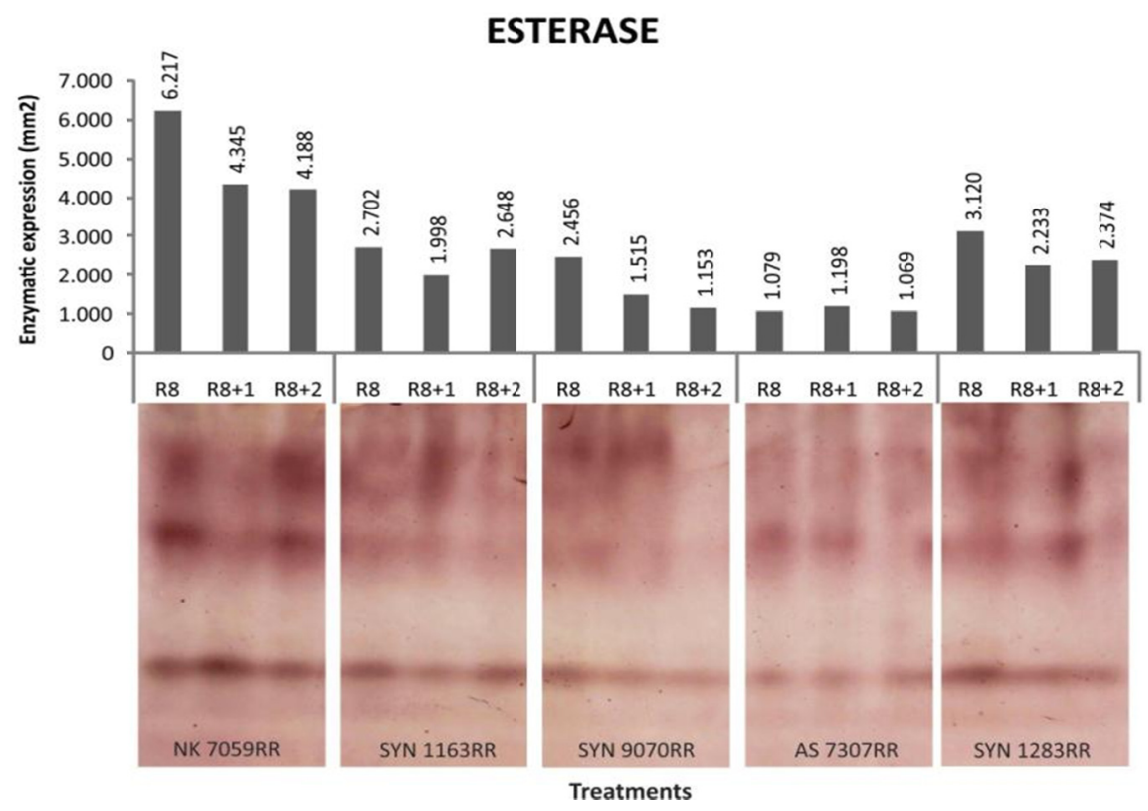

Figure 8. Esterase enzyme expression at 180 days of storage of different soybean seeds cultivars submitted to harvest delay and artificial rainfall in pre-harvest (R8; $\mathrm{R} 8+1$ rainfall in pre-harvest; $\mathrm{R} 8+2$ rainfalls in pre-harvest)

The decrease in esterase expression shows a higher membrane lipid peroxidation, which may be related to membrane degradation and permeability process (Vieira et al., 2013).

For soybean seeds harvested at different harvest seasons with artificial rainfall and regarding the expression of the enzyme isocitratelyase (ICL) through electrophoresis technique, it is verified that seeds not submitted to storage (Figure 9) show similarity in the intensity of bands that express this enzyme, indicating few variations in the rate of enzymatic degradation of the lipid reserves of seeds. Zuffo et al. (2017b) when studying ICL enzyme expression on soybean seeds submitted to harvest delay, found that lower activity variation was reported until 20 days after the R8 stage, as well as a prominent reduction from 25 days of harvest delay and onwards.

The ICL enzymatic activity decreased fromzero to 180 days of storage. This can happen because ICL can be involved in decreasing of physiological quality with storage. Moreno at al. (2019) and Carvalho et al. (2014) observed lower activity in soybean seeds with lower physiological quality.

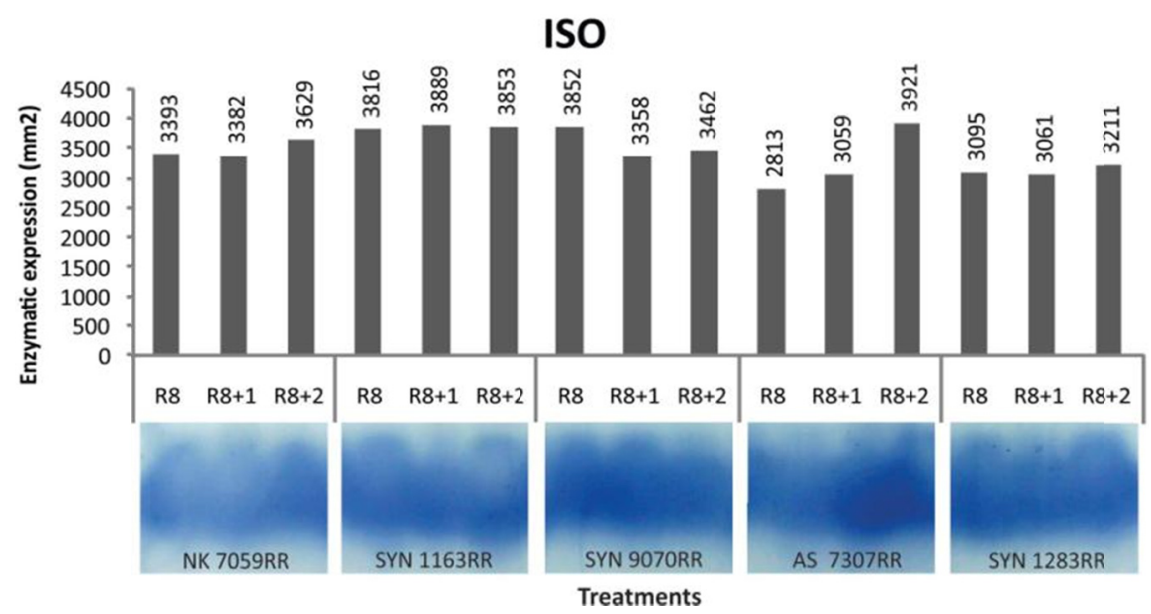

Figure 9. Isocitratelyase enzyme expression at zero days of storage of different soybean seeds cultivars submitted to harvest delay and artificial rainfall in pre-harvest (R8; R8+1 rainfall in pre-harvest; $\mathrm{R} 8+2$ rainfalls in pre-harvest) 
At 180 days of storage (Figure 10), the cultivars NK 7059 RR and SYN 1163 RR showed no differences among the harvesting seasons. The higher ICL expression in seeds from cultivars AS 7307 RR and SYN 1283 RR may be related to the vigor of these seeds, a fact confirmed by Martin et al. (2000). These authors found higher values for ICL expression in the Doko variety, recognized for their physiological quality when compared to values obtained in the cultivar CAC-1 and submitted to the cold test, accelerated aging, and germination test.

\section{ISO}

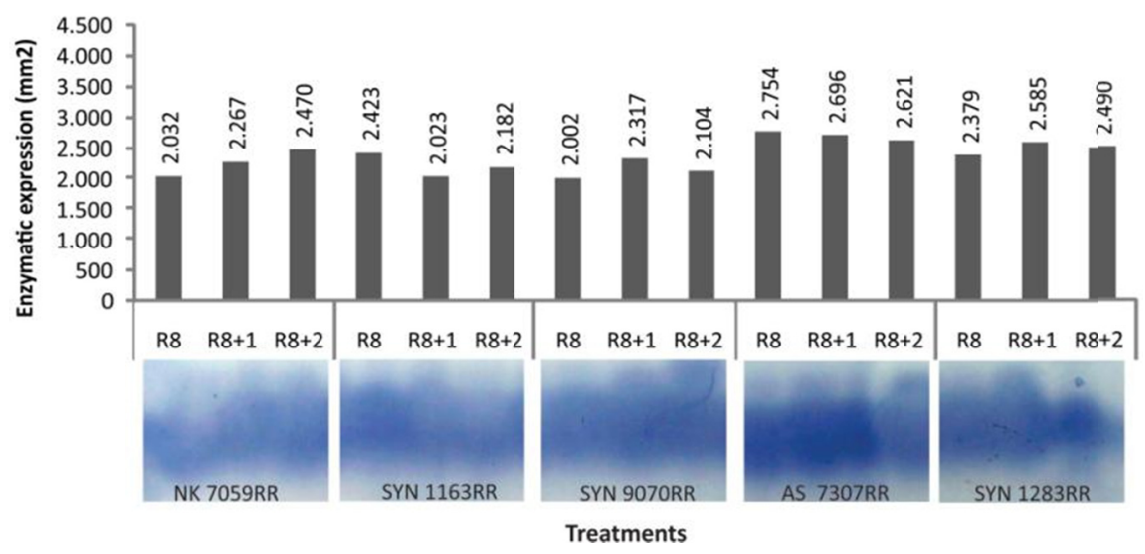

Figure 10. Isocitratelyase enzyme expression at 180 days of storage of different soybean seeds cultivars submitted to harvest delay and artificial rainfall in pre-harvest $(\mathrm{R} 8$; $\mathrm{R} 8+1$ rainfall in pre-harvest; $\mathrm{R} 8+2$ rainfalls in pre-harvest)

In soybean seeds, ICL is considered a key enzyme in regulating the glyoxylate cycle and is involved in the metabolism of stored lipids in oilseeds and in the development of activities in glyoxysomes (Pires et al., 2017). The expression of this enzyme increases during seed germination, obtaining maximum values when the maximum ratio of degraded lipids occurs in the sucrose synthesis (Bewley et al., 2013).

Baldoni et al. (2013) also studied with delay in the harvest of soybean seeds and observed lower expression of the enzyme in seeds harvested in the R8 stage in relation to those harvested 15 days after the R8 stage for two of the three studied cultivars.

\section{Conclusion}

The cultivar AS 7307 RR presents higher lignin content and better physiological quality, which are also confirmed by the enzymatic activity.

There is variation in the electrophoretic pattern of the enzymes catalase, esterase, alcohol dehydrogenase; malate dehydrogenase, and isocitratelyase for seeds subjected to harvest delay and artificial incidence of rainfall, both at the beginning and at 180 days of storage.

The genotype influences vigor, enzyme activity, and storage potential.

\section{Acknowledgements}

The authors thank the Foundation for Supporting Research of the State of Minas Gerais (FAPEMIG), the National Council for Scientific and Technological Development (CNPq) and the Coordination for the Improvement of Higher Education Personnel (CAPES) for financial support during this study.

\section{References}

Alfenas, A. C. (2006). Eletroforese e marcadores bioquímicos em plantas e microrganismos (p. 627). Viçosa: Editora UFV.

Baldoni, A., Von Pinho, E. V. R., Fernandes, J. S., Abreu, V. M., \& Carvalho, M. L. M. (2013), Gene expression involved in the lignin biosynthesis pathway during soybean seed development. Genetics and Molecular Research, 12(3), 2618-2624. https://doi.org/10.4238/2013.February.28.2

Baldoni, A., Von Pinho, E. V. R., Santos, H. O., Marques, T. L., \& Pereira, R. W. (2019). Gene expressions enalysis of seed physiological quality in soybean cultivars. Journal of Agricultural Science, 11(2), 408-419. https://doi.org/10.5539/jas.v11n2p408 
Bellaloui, N., Smith, J. R., \& Mengistu, A. (2017). Seed Nutrition and Quality, Seed Coat Boron and Lignin Are Influenced by Delayed Harvest in Exotically-Derived Soybean Breeding Lines under High Heat. Frontiers Plant Science, 22(8), 1-16. https://doi.org/10.3389/fpls.2017.01563

Bewley, J. D., Bradford K. J., Hilhorst H. W. M., \& Nonogaki, H. (2013). Seeds: Physiology of Development, Germination and Dormancy (p. 392). New York: Springer. https://doi.org/10.1007/978-1-4614-4693-4

Caixeta, F., Von Pinho, E. V. D. R., Guimarães, R. M., Pereira, P. H. A. R., Catão, H. C. R. M., Clemente, A. D. C. S. (2014). Determinação do ponto de colheita na produção de sementes de pimenta malagueta e alterações bioquímicas durante o armazenamento e a germinação. Científica, 42(2), 187-197. https://doi.org/10.15361/ 1984-5529.2014v42n2p187-197

Capeleti, I., Ferrarese, M. L. L., Krzyzanowski, F. C., \& Ferrarese Filho, O. (2005). A new procedure for quantification of lignin in soybean (Glycine $\max$ (L.) Merrill) seed coat and their relationship with the resistance to mechanical damage. Seed Science and Technology, 33(2), 511-515. https://doi.org/10.15258/ sst.2005.33.2.25

Carvalho, E. R., Oliveira, J. A., Von Pinho, E. V. R., \& Costa Neto, J. (2014). Enzyme activity in soybean seeds produced under foliar application of manganese. Ciência e Agrotecnologia, 38(4), 317-327. https://doi.org/ 10.1590/S1413-70542014000400001

Castro, D. G., Bruzi, A. T., Zambiazzi, E. V., Rezende, P. M., Zuffo, A. M., Sales, A. P., ... Bianchi, M. C. (2017). Qualidade fisiológica e expressão enzimática de sementes de soja RR®. Revista de Ciências Agrárias, 40(1), 222-235. https://doi.org/10.19084/RCA16054

Catao, H. C. R. M., Gomes, L. A. A., Guimarães, R. M., Fonseca, P. H. F., Caixeta, F., \& Marodin, J. C. (2016). Physiological and isozyme alterations in lettuce seeds under different conditions and storage periods. Journal of Seed Science, 38(4), 305-313. https://doi.org/10.1590/2317-1545v38n4163863

Cavariani, C., Toledo, M. Z., Rodella, R. A., França Neto, J. B., \& Nakagawa, J. (2009). Velocidade de hidratação em função de características do tegumento de sementes de soja de diferentes cultivares e localidades. Revista Brasileira de Sementes, 31(1), 30-39. https://doi.org/10.1590/S0101-31222009000100004

Dutra, A. S., \& Vieira, R. D. (2004). Envelhecimento acelerado como teste de vigor para sementes de milho e soja. Ciência Rural, 34(3),715-721. https://doi.org/10.1590/S0103-84782004000300010

Felisberto, G., Bruzi, A. T., Zuffo, A. M., Zambiazzi, E. V., Soares, I. O., Rezende, P. M., \& Botelho, F. B. S. (2015). Agronomic performance of RR ${ }^{\circledR}$ soybean cultivars using different pre-sowing desiccation periods and distinct post-emergence herbicides. African Journal of Agricultural Research, 10(34), 3445-3452. https://doi.org/10.5897/AJAR2015.9853

Ferreira, T. F., Ferreira, V. F., Oliveira, J. A., Carvalho, M. V., \& Miguel, L. S. (2015). Isoenzyme activity in maize hybrid seeds harvested with different moisture contents and treated. Journal of Seed Science, 37(2), 139-146. https://doi.org/10.1590/2317-1545v37n2147183

Galvão, J. C. C., Conceição, P. M., Araújo, E. F., Karsten, J., \& Finger, F. L. (2014). Alterações fisiológicas e enzimáticas em sementes de milho submetidas a diferentes épocas de colheita e métodos de debulha. Revista Brasileira de Milho e Sorgo, 1(1),14-23. https://doi.org/10.18512/1980-6477/rbms.v13n1p14-23

Hu, D., Ma, G., Wang, Q., Yao, J., Wang, Y., Pritchard, H. W., \& Wang, X. (2012). Spatial and temporal nature of reactive oxygen species production and programmed cell death in elm (Ulmus pumila L.) seeds during controlled deterioration. Plant, Cell and Environment, 35(11), 2045-2059. https://doi.org/10.1111/ j.1365-3040.2012.02535.x

Huth, C., Mertz-Henning, L. M., Lopes, S. J., Tabaldi, L. A., Rossato, L. V., Krzyzanowski, F. C., \& Henning, F. A (2016). Susceptibility to weathering damage and oxidative stress on soybean seeds with different lignin contents in the seed coat. Journal of Seed Science, 38(4), 296-304. https://doi.org/10.1590/2317-1545 v38n4162115

Jeevan Kumar, S. P., Prasad, S. R., Banerjee, R., \& Thammineni, C. (2015). Seed birth to death: Dual functions of reactive oxygen species in seed physiology. Annals of Botany, 116(4), 663-668. https://doi.org/10.1093/ aob/mcv098

MAPA (Ministério da Agricultura, Pecuária e Abastecimento). (2009). Regras para análise de sementes (p. 395). Brasília, Brazil. 
Martins, C. A. O., Carlos, S. S., Maria, G. de A. O., Inês, C. J., Maurílio, A. M., Múcio, S. R., \& Valterley, S. R. (2000). Atividade da isocitrato-liase durante a germinação de sementes de soja. Revista Brasileira de Sementes, 22(1), 42-46. https://doi.org/10.17801/0101-3122/rbs.v22n1p42-46

Moreno, K. A. A., Pires, R. M. O., Castro, M. L. R., Vasconsellos, R. C. C., Santos, H. O., Pinho, E. V. R. V. (2019) Gene expression related to physiological quality of soybean seeds. Journal of Agricultural Science, 11(3), 370-380. https://doi.org/10.5539/jas.v11n3p370

Ometo, J. C. (1981). Bioclimatologia vegetal (p. 525). São Paulo: Agronômica Ceres.

Pires, R. M. O., Àvila, M. A. B., Leite, D. G., Santos, H. O., Souza, G. A., \& Von Pinho, E. V. R. (2017). Physiological and enzymatic alterations in sesame seeds submitted to different osmotic potentials. Geneticsand Molecular Research, 16(3), 1-7. https://doi.org/10.4238/gmr16039425

Santos, H. O., Botelho, F. B. S., Uenojo, R. K., Fonseca, A. C. A., Mendes, M. P., Von Pinho, E. V. R., \& Carvalho, M. L. M. (2015). Phenotypic and Enzymatic Analyses of Upland Rice Lines Seeds under No-Tillage. American Journal of Plant Sciences, 6, 1981-1989. https://doi.org/10.4236/ajps.2015.612199

Santos, H. O., Von Pinho, I. V., de Oliveira Pires, E. R., da Silva V. I. F., de Carvalho, M. L. M., \& Oliveira, R. M. E. (2016). Physiological quality of hybrid maize seeds through respiratory and enzymatic activities. African Journal of Agricultural Research, 11(20), 1879-1886. https://doi.org/10.5897/AJAR2015.10457

Taiz, L., \& Zeiger, E. (2013). Plant physiology (5th ed., p. 918). Porto Alegre: Artmed.

Timóteo, T. S., \& Marcos Filho, J. (2013). Seed performance of different corn genotypes during storage. Journal of Seed Science, 35(2), 207-215. https://doi.org/10.1590/S2317-15372013000200010

Veiga, A. D., Von Pinho, E. V. R., Veiga, A. D., Pereira, P. H. A. R., Oliveira, K. C., \& Von Pinho, R. G. (2010). Influência do potássio e da calagem na composição química, qualidade fisiológica e na atividade enzimática de sementes de soja. Ciência e Agrotecnologia, 34(4), 953-960. https://doi.org/10.1590/S1413-70542 010000400022

Vieira, B. G. T. L., Barbosa, R. M., UnedaTrevisoli, S. H., Mauro, A. O., \& Vieira, R. D. (2013). Biochemical alterations in soybean seeds with harvesting time and storage temperature. International Journal of Food, Agriculture and Environment, 11(3), 887-891.

Zuffo, A. M., Zuffo Júnior, J. M., Carvalho, E. R., Steiner, F., \& Zambiazzi, E. V. (2017b). Physiological and enzymatic changes in soybean seeds submitted to harvest delay. Pesquisa Agropecuária Tropical, 47(4), 488-496. https://doi.org/10.1590/1983-40632017v4749811

Zuffo, A. M., Zuffo Junior, J. M., Zambiazzi, E. V., \& Steiner, F. (2017a). Physiological and sanitary quality of soybean seeds harvested at different periods and submitted to storage. Pesquisa Agropecuária Tropical, 47(3), 312-320. https://doi.org/10.1590/1983-40632016v4747576

\section{Copyrights}

Copyright for this article is retained by the author(s), with first publication rights granted to the journal.

This is an open-access article distributed under the terms and conditions of the Creative Commons Attribution license (http://creativecommons.org/licenses/by/4.0/). 